Review Article

\title{
Therapeutic Strategies for Dry Mouth Management with Emphasis on Electrostimulation as a Treatment Option
}

\author{
Amela Tulek $\mathbb{D},{ }^{1}$ Aida Mulic $\mathbb{D}^{2},{ }^{2}$ Martine Hogset, ${ }^{1}$ Tor Paaske Utheim $\left(\mathbb{D},{ }^{1,3,4}\right.$ \\ and Amer Sehic (iD ${ }^{1,3}$ \\ ${ }^{1}$ Department of Oral Biology, Faculty of Dentistry, University of Oslo, Oslo, Norway \\ ${ }^{2}$ Nordic Institute of Dental Materials (NIOM), Oslo, Norway \\ ${ }^{3}$ Department of Maxillofacial Surgery, Oslo University Hospital Ullevaal, Oslo, Norway \\ ${ }^{4}$ Department of Medical Biochemistry, Oslo University Hospital, Oslo, Norway
}

Correspondence should be addressed to Amela Tulek; amela.tulek@odont.uio.no

Received 5 July 2021; Revised 6 October 2021; Accepted 7 October 2021; Published 22 October 2021

Academic Editor: Boonlert Kukiattrakoon

Copyright (C) 2021 Amela Tulek et al. This is an open access article distributed under the Creative Commons Attribution License, which permits unrestricted use, distribution, and reproduction in any medium, provided the original work is properly cited.

Objectives. Xerostomia is a subjective sensation of dry mouth. It is commonly associated with salivary gland hypofunction. Both changes in the composition of the saliva and a reduction in the quantity secreted may be an objective finding of dry mouth. Although there are no currently available cures for the conditions resulting in dry mouth, there are several treatment options that give hope for patients who suffer from xerostomia. Individuals with some residual salivary gland function, which are contraindicated to pharmacological therapies, would benefit the most from identifying novel, alternative effective methods for stimulating production of saliva. The aim of this study was to give an overview of the latest and most relevant data related to treatment modalities for the management of dry mouth conditions. Data Resources and Study Selection. The present review was prepared by searching the National Library of Medicine database using the relevant medical terms and their combinations. A total of thirty-three studies met the inclusion criteria. Data were extracted by one author and verified by another. Conclusion. A number of patients showed positive treatment outcomes, and the adverse effects of both electrical stimulation (ES) and acupuncture have been reported as mild and transient. In patients who have undergone radiotherapy, acupuncture is shown to increase salivation. However, in patients with Sjogren's syndrome, the effects of ES devices seem to be elusive. Moreover, due to the instability of the findings in relation to longevity of clinical effect, patient satisfaction, quality of life, and clinical effectiveness of such treatments, the results remain vague.

\section{Saliva and Oral Implications}

The multiple functions of saliva, which are linked to its specific components and fluid characteristics, are crucial for maintaining the hypotonic environment; remineralization of dental enamel; control of the composition of oral microflora with its antibacterial, antiviral, and antifungal properties; mastication and swallowing; digestion of food; articulation of speech; and many other functions [1-4]. Approximately $0.6 \mathrm{~L}$ of saliva is excreted daily by major and minor salivary glands $[5,6]$.

The secretion of salivary components is dependent upon the autonomic nervous system and regulated by several reflexes. The masticatory and gustatory afferent impulses, and thermoreceptive, olfactory, nociceptive, and psychic stimuli influence activation of the salivary gland cells [7-9]. These afferent sensory impulses are transmitted to the salivation center in the brainstem (parasympathetic), to the upper thoracic segments of the spinal cord (sympathetic), and to higher brain structures, which may react with both inhibitory and excitatory efferent signals to the salivatory nuclei and thereby salivary glands [10].

Furthermore, the function of salivary glands is under the influence of many stimuli and factors, which can affect the flow, volume, and composition of saliva. It has been shown that the expression of aquaporin 5 and of specific clock genes involved in the regulation of circadian rhythms is subject to diurnal pattern in gene expression in mouse submandibular gland cells [11]. Thus, it is suggested that the molecular underpinnings orchestrating normal salivary secretion may 
be influenced by the circadian clock, which also may play a role in different pathologies of salivary glands [12]. The size of the glands and the level of hydration of the body are other factors related to salivary flow rates [13-16].

From the clinical aspect, both changes in the composition of saliva and a reduction in the quantity secreted may be an objective finding of dry mouth [17, 18]. Dry mouth is a common problem in the general population with a prevalence between $10 \%$ and $33 \%$, being more common in females $[19,20]$. Although xerostomia more frequently affects the elderly, it may also be present in young adults [21, 22]. The subjective sensation of dry mouth in the older population may probably be attributed to other factors than age-related degenerative changes [23]. The higher prevalence of chronic conditions and the resultant general "polypharmacy" with wide use of various anticholinergic medications are considered as important factors $[20,24]$. Several medications, including commonly prescribed preparations, such as those used to treat hypertension, epilepsy, and depression, are reported to cause dry mouth through different mechanisms [20, 24].

In general, causes of xerostomia can be divided into two main groups: nonsalivary and salivary [17]. Nonsalivary causes of oral dryness may include dehydration, anxiety, mouth breathing, and neurological dysfunction [17], whereas the salivary causes of dry mouth are associated with pathological changes in salivary glands. A number of patients with systemic autoimmune diseases such as Sjogren's syndrome, systemic lupus erythematosus, rheumatoid arthritis, systemic sclerosis, and sarcoidosis suffer from dry mouth $[25,26]$. Exocrine glands in those patients become infiltrated with immune cells, predominantly CD4+ lymphocytes T-cells. The lymphocytes further induce the production of different cytokines that alter saliva secretion [27]. Simultaneously, an increased activity of certain matrix metalloproteinase, with a decrease in production of tissue inhibitors of such proteolytic enzymes, is found in those patients [28]. Disturbance of saliva production is also reported in patients with diabetes mellitus, obesity, hypertension, chronic kidney disease and chronic heart failure [29-34]. Common in those patients is increased predisposition to oxidative stress. Products of oxidation can aggregate and accumulate in the salivary glands leading to damage of secretory cells and increase in the formation of reactive oxygen species. This may enhance local oxidative stress even more [35-37].

A noteworthy correlation was found between salivary gland hypofunction, followed by xerostomia and patients suffering from dementia $[38,39]$. One plausible explanation is that neurological centers orchestrating function of salivary glands are impaired in those patients. However, this field requires more research in order to draw affirmative conclusions.

Xerostomia was reported in majority of COVID-19 patients. Since the virus has neuropathic and mucotropic effects on the salivary gland tissues, it is hypothesized that it alternates the structure and function of the gland at some point. As xerostomia occurs prior to other common symptoms of infection, this information could be used as an early diagnostic mark [40].
Furthermore, dry mouth is a common side effect of both chemotherapy and radiotherapy during the treatment of cancer $[20,41]$.

Since the treatment of chronic diseases becomes more effective and the life expectancy increases, it is also reasonable to assume that the number of people living with xerostomia will be higher [20,23]. Dry mouth conditions may impact the quality of life in several ways. This includes difficulties with speech, chewing, and swallowing of food, due to the dehydrated mucosa [42]. Taste sensation can be impaired and tenderness of the oral mucosa and gums makes the wearing of dentures difficult. Infections in salivary glands, oral candidiasis, and increased incidence of root caries have been reported $[18,43,44]$. A positive correlation between xerostomia and/or hyposalivation and caries activity in a population of younger adult patients has been shown recently [45]. Patients with subjective sensation of dry mouth complain of burning mouth syndrome [46]. Furthermore, psychological discomfort and impaired sleep may be another consequence. Finally, majority of patients can feel stigmatized, as their condition is often not taken seriously by others. This leads to social withdrawal and diminished self-esteem [42]. Effective treatment of patients with dry mouth is therefore important in order to improve the quality of life of sufferers, and, in addition, from both a patient and public health perspective it is of outmost importance to treat dry mouth symptoms and minimize potentially painful oral infections and costly tooth loss.

Since xerostomia may affect the quality of life in individuals, the main aim of this study was therefore to provide an overview of the latest and most relevant findings related to treatment modalities for the management of dry mouth conditions.

\section{Data resources and Study Selection}

Data collected from the National Library of Medicine database were used in this study. The search was conducted with the different combinations of the following terms: ("dry mouth" OR "xerostomia" OR "hyposalivation") AND ("treatment") AND ("electrical stimulation" OR "electrotherapy" OR "acupuncture") in an attempt to reveal relevant publications. The search was performed without restriction with regard to the language and study design. Selection criteria included articles published from 1981 to the present year. Primary search yielded 187 studies. All authors thereafter reviewed the titles and abstracts of the selected articles. Eventually, duplicates were excluded. Articles were also rejected if they were clearly unqualified. In case where updated versions of the paper were found, older versions were rejected. The authors then reviewed the remaining articles to determine their eligibility. Finally, thirty-three studies were accessed.

2.1. Current Treatment Options. Although there are no currently available cures for the conditions resulting in dry mouth, different treatment options give hope for patients who suffer from xerostomia. The most commonly used 
approaches are the use of salivary substitutes and increased fluid intake, which aim to treat the symptoms. Some individuals may manage the problems associated with dry mouth through optimal handling of the underlying conditions [23]. For patients with milder symptoms, frequent sips of water and sucking of ice chips may result in sufficient relief [19]. It is recommended to reduce/avoid the consumption of alcoholic drinks, caffeine, and smoking as they additionally dehydrate the oral mucosa $[47,48]$. Topical application of oral rehydrating agents acts directly on the surface of the oral mucosa and may provide short-term relief [24]. It has been shown that the use of oral moisturizers and toothpastes result in significant improvements in whole unstimulated salivary flow rate, a decrease in colonization with Candida, and a subjective improvement of xerostomia in patients with primary Sjogren's syndrome and subjects that had undergone radiotherapy for head and neck cancer $[49,50]$. It is important to note that the utility of artificial saliva products is to some extent limited in xerostomia treatment, due to the different composition of artificial saliva compared to human saliva with respect to $\mathrm{pH}$ values, osmolality, and electrical conductivity [51].

The symptomatic treatment of xerostomia by means of topical medications stimulating saliva production or increased fluid intake may be sufficient for patients with some degree of preserved salivary gland function [20]. However, in patients with permanent destruction of salivary acini, in addition to palliative therapy, other forms of both local and systemic treatment may be necessary in order to induce secretions from the remaining salivary gland tissue. The two most common systemic agents are pilocarpine and cevimeline, which both act as the agonist for the muscarinic receptors on the surface of the salivary cells [52]. Several clinical studies have demonstrated that the use of pilocarpine results in significant improvement in symptoms associated with xerostomia [53-55]. However, since it is a cholinergic agent, it is associated with several side effects like increased sweating and lacrimation, frequent urination, nausea, headache, rhinitis, and gastrointestinal disturbances [56]. Cevimeline is an analog of acetylcholine and gives the same amount of relief from symptoms of dry mouth as pilocarpine. However, due to its high affinity to the M3 sub-receptor type, which is specific to the salivary gland tissue, it has fewer side effects compared to pilocarpine [52]. Bethanechol and anethole trithione are other drugs that exert their function via the parasympathetic system and have been shown to have some effect on dry mouth symptoms [52]. A study conducted on head and neck radiation therapy patients treated with either bethanechol or pilocarpine suggested that both medications have nearly the same effect on saliva production [57]. It is also worth mentioning another medicine, amifostine, currently the only medicine used in an attempt to prevent xerostomia in radiation therapy patients, due to its ability to scavenge free radicals [58].

Gene therapy in the treatment of dry mouth is based on delivery of genes into the salivary glands. Although it may become a therapeutic strategy for radiation-induced salivary hypofunction in the future, current therapies are primarily experimental, with most studies performed in animal models [59]. One clinical trial employing gene delivery to salivary gland in head and neck irradiated participants studied gene transfer utilizing the first-generation serotype 5 , adenoviral (Ad5) vector coding for human aquaporin-1 (hAQP1) [60]. AQP1, expressed in the myoepithelial and endothelial cells of the human [61,62], is a water channel protein that facilitates fluid transfer by an osmotic gradient [63]. Delivery of AdhAQP1 vector to a single parotid gland was found to be safe and the results demonstrated that the transfer of the hAQP1 cDNA increased the flow in parotid gland and relieved symptoms in a subset of patients [64]. The improvements in these patients persisted for several years after the one-time treatment. At present, there are two ongoing clinical trials evaluating the delivery of aquaporin-1 (AQP1) via adeno-associated viral vector 2 (AAV2) to the parotid gland in human patients with radiation-induced salivary gland hypofunction $[65,66]$. Both studies are in phase 1 with the estimated study completion in 2022.

Another potential approach in regeneration of salivary gland tissue is the use of stem cells. Although clinical trials are mostly in its early phases, the obtained results in radiation-induced xerostomic patients seem to be promising [67]. The stem cells used in dry mouth treatment are mainly mesenchymal/stromal cells harvested from umbilical cord blood, bone marrow, or adipose tissue [68-71]. However, due to their potential to metastasize to other tissues, the long-term safety of these cells is yet to be investigated.

The quality of life of a patient suffering from radiationinduced xerostomia may be significantly reduced. Therefore, the use of low-power laser light for analgesive and antiinflammatory effect has been suggested. The laser light that is transformed into energy for the cells improves microcirculation, glandular cell proliferation, cellular respiration, ATP production, protein synthesis, and intracellular calcium levels [72]. Having in mind that this technique is noninvasive and noncostly, it could be used in xerostomia treatment.

Intraglandular administration of botulinum toxin prior to radiation treatment is another promising approach in the treatment of radiation-induced xerostomia. Although the mechanism of action is not yet clear, it is suggested that botulinum toxin reduces nerve stimulation and saliva production, thereby reducing the sensitivity of glandular cells to radiation. However, agreements for the use of this technique are still in the establishment phase [73, 74].

\subsection{Electrical Stimulation as a means for Treating Dry} Mouth. Electrical activity is essential for the development, function, and survival of neurons [75]. Already in 1791, Luigi Galvani`s animal experiments demonstrated that the application of electrical current resulted in contractions in the muscles of frog legs. Since then, it has been known that electrical stimulation (ES) may be a common rehabilitative strategy to restore function in muscle and neural tissues. Cardioversion and defibrillation further illustrate the huge therapeutic potential of ES in medicine, and evolving research has provided evidence that ES of the eye may be a 
TABLE 1: Electrical stimulation for treating dry mouth in human trials.

\begin{tabular}{cc}
\hline Reference & Disease \\
\hline & \\
& \\
& \\
& (1) Sjögren's \\
syndrome, $N=9$ \\
(2) Undergone head
\end{tabular}

Weiss et al. and neck radiation

[79] therapy, $N=13$

(3) Xerostomia being

either drug-induced or

unknown etiology,

$$
N=3
$$

Stimulation location and
parameters
Electrodes placed on the
dorsum of the tongue
and pressed against the
hard palate; the
maximum voltage was
$6 \mathrm{~V}$ with a current of
$9 \mathrm{uA}$; the maximum
power was $12.4 \mathrm{~mJ}$ in a 3
minute stimulus cycle;
the stimulus was
increased until the
patients reached their
level of tolerance.

Control group $\quad$ Evaluation method

Results/conclusion

Subjective patient evaluation was performed Intraoral clinical examination was performed.
This noninvasive electrostimulation has shown to be effective in patients with xerostomia due to Sjögren's syndrome or radiation therapy; patients reported slight to substantial improvement.
Electrodes placed on the dorsum of the tongue and pressed against the hard palate.

An intensity control knob with intervals from

Steller et al. Sjögren's syndrome, 0 to 10 set peak stimulus [82]

$$
N=29
$$

Placebo device and output between 0 and $6 \mathrm{~V}$; the maximum average current output is $9 \mathrm{uA}$ and corresponds to a maximum average power dissipation of $0.2 \mathrm{uW}$.
Subjective patient evaluation was performed.

Intraoral clinical

examination was performed

The whole saliva flow rates were measured.
The mean

poststimulation whole saliva flow rate of subjects using the active device increased, while the mean poststimulation rate of those using a placebo device did not

$(P=0.04)$. The results in this study indicate that some Sjögren's syndrome patients with residual salivary flow show a significant response to electrical stimulation, but others with low or absent whole saliva flow rates do not respond.

The patients using active devices showed a statistically greater $(P=0.005$ to 0.02$)$ increase in the production of saliva compared to control. At week 1 , the differences between the prestimulation and poststimulation salivary production was $80 \%$ greater in the group with the active device than in the control group; the differences were $151 \%$ at week 2 and $116 \%$ at week 
TABle 1: Continued.

\begin{tabular}{|c|c|c|c|c|c|}
\hline Reference & Disease & $\begin{array}{l}\text { Stimulation location and } \\
\text { parameters }\end{array}$ & Control group & Evaluation method & Results/conclusion \\
\hline
\end{tabular}

Both groups showed significantly increased salivary flow rates after the acupuncture treatment. In the

Blom et al. Undergone head and [84] neck radiation
therapy, $N=38$

Classical acupuncture was used.
Classical

acupuncture and superficial acupuncture as placebo
Manual acupuncture and acupuncture with

Dawidson et al. [85]
Healthy subjects, $N=8$ low-frequency electrical stimulation $(2 \mathrm{~Hz})$ were used.
Blom et al. Sjogren's syndrome, [86] causes, $N=70$
Acupuncture and twoway ANOVA were used.
Codetron treatment was given twice weekly for 6 weeks. Nonpolarizing, balanced biphasic, square electrical pulses of $250 \mathrm{~ms}$ duration were delivered in trains with a repetition rate of $4 \mathrm{hz}$.

Each acupuncture point was randomly stimulated for $10 \mathrm{~s}$ each time; each session of codetron treatment lasted for a total of $20 \mathrm{~min}$; this was followed by a 2 -week break and then another 6-week course of treatment was repeated.
The whole saliva flow rates were measured.

The quality of life questionnaire assessments were performed.
Immunoreactivity of neuropeptides was analyzed in the saliva collected 20 minutes before the start of acupuncture stimulation, then for 20 minutes while the needles were in situ, and the for another 20 minutes after the needles were removed. Salivary flow rates (SFR) for whole unstimulated and stimulated saliva were used as indicators of effects. Data were analyzed 6 month following a baseline course of 24 acupuncture treatments using two-way ANOVA.
The results showed significant increases in the release of CGRP, NPY, and VIP both during and after acupuncture stimulation, especially in connection with electroacupuncture.
Statistically significant differences in unstimulated and stimulated salivary flow rates $(P<0.01)$ in all etiological groups after 24 acupuncture treatments and up to 6 months follow-up compared with baseline. Improvement in xerostomia symptoms was noted, with a mean increase in the visual analog scale score of 86 $(P<0.0005)$ and 77 $(P<0.0001)$ at 3 and 6 months after treatment completion, respectively. For all patients, the increase in the mean basal and citric acidprimed whole saliva production at 3 and 6 months after treatment completion was also statistically significant $(P<0.001$ and $P<0.0001$, respectively). No statistically significant change in the quality-of-life evaluation compared with baseline was observed. 
TABle 1: Continued.

\begin{tabular}{|c|c|c|c|c|}
\hline Reference & Disease & $\begin{array}{l}\text { Stimulation location and } \\
\text { parameters }\end{array}$ & Control group & Evaluation method \\
\hline $\begin{array}{l}\text { Hargitai et } \\
\text { al. [88] }\end{array}$ & $\begin{array}{l}\text { Healthy subjects, } \\
\qquad N=22\end{array}$ & $\begin{array}{l}\text { The TENS electrode pads } \\
\text { were placed externally } \\
\text { on the skin overlying } \\
\text { parotid glands. The pulse } \\
\text { rate was fixed at } 50 \mathrm{~Hz} \text {, } \\
\text { the pulse duration } \\
250 \mu \mathrm{sec} \text {, and the unit } \\
\text { was in normal mode. }\end{array}$ & - & $\begin{array}{l}\text { Unstimulated saliva was } \\
\text { collected for } 5 \text { minutes } \\
\text { via the carlson- } \\
\text { crittenden cup placed } \\
\text { over Stensen's duct } \\
\text { bilaterally, into } \\
\text { preweighted vials. The } \\
\text { TENS unit was then } \\
\text { activated, and } \\
\text { stimulated saliva } \\
\text { collected for an } \\
\text { additional } 5 \text { minutes. }\end{array}$ \\
\hline
\end{tabular}

\begin{tabular}{|c|c|c|c|c|}
\hline $\begin{array}{l}\text { Strietzel et } \\
\text { al. [89] }\end{array}$ & $\begin{array}{c}\text { Subjects with } \\
\text { xerostomia, } N=23\end{array}$ & $\begin{array}{l}\text { Electrostimulation } \\
\text { device named } \\
\text { GenNarino; delivered } \\
\text { during } 10 \text { min to the oral } \\
\text { mucosa, in the } \\
\text { mandibular third molar } \\
\text { region (close to the area } \\
\text { where the lingual nerve } \\
\text { travels alongside the } \\
\text { lingual alveolar plate). }\end{array}$ & $\begin{array}{l}\text { Sham (inactive } \\
\text { stimulation) }\end{array}$ & $\begin{array}{l}\text { The digital signal of the } \\
\text { wetness sensor } \\
\text { expressed in numbers } \\
\text { was used as a measure of } \\
\text { dryness. }\end{array}$ \\
\hline
\end{tabular}

The effect was evaluated by measuring whole salivary flow rates and questionnaire-based
Acupuncture was

Cho et al. Undergone head and [90] neck radiation therapy, $N=12$ conducted twice weekly for 6 weeks in a singleblind setting.
Randomized into two groups: Real or sham acupuncture assessment of subjective

symptoms pretreatment and posttreatment $(3$

and 6 weeks after acupuncture treatment).

After 3 min of the $5 \mathrm{~min}$ experiments, significantly lower dryness was seen in the active modes compared with sham. No significant side effects were observed.

Both groups showed a slight increase in whole salivary flow rates, with no significant differences between them. Real acupuncture markedly increased unstimulated salivary flow rates, and improved the score for dry mouth according to the xerostomia questionnaire, by 2.33 points versus 0.33 in the controls.

\footnotetext{
A Saliwell Crown was placed in the lower third molar area, in vicinity to the lingual nerve. The stimulating device is mounted on a commercially available dental implant. The Saliwell Crown is composed of an electric circuit, two $1.5 \mathrm{~V}$ batteries, a microprocessor, a wetness sensor, an IR receiver, and stimulating electrodes.
}

Both stimulated and unstimulated saliva flow rates were measured. Subjective patient evaluation was performed.
The results showed a constant significant increase in the salivary secretion and symptomatic improvement as presented in the questionnaires. The frequency of dry and burning mouth has decreased during the study. 
TABle 1: Continued.

\begin{tabular}{|c|c|c|c|c|c|}
\hline Reference & Disease & $\begin{array}{c}\text { Stimulation location and } \\
\text { parameters }\end{array}$ & Control group & Evaluation method & Results/conclusion \\
\hline $\begin{array}{l}\text { Pattani et } \\
\text { al. [92] }\end{array}$ & $\begin{array}{l}\text { Undergone head and } \\
\text { neck radiation } \\
\text { therapy, } N=5\end{array}$ & $\begin{array}{l}20 \text { one-hour sessions } \\
\text { with TENS unit; } \\
\text { electrode pads placed } \\
\text { externally on the skin } \\
\text { overlying the parotid } \\
\text { glands bilaterally; } \\
\text { stimulation was initiated } \\
\text { using } 4 \text { to } 30 \mathrm{~mA} \text { at } \\
80-100 \text { impulses. The } \\
\text { settings ranged from } 55 \\
\text { to } 80 \mathrm{~mA} \text { (maximum } \\
\text { setting). The duration of } \\
\text { treatment was } 60 \\
\text { minutes per session. } \\
\text { Patients received three } \\
\text { E-stimulation treatments } \\
\text { per week for a total of } \\
\text { one to two months. }\end{array}$ & - & $\begin{array}{l}\text { The whole saliva flow } \\
\text { rates were measured. } \\
\text { Dysphagia and } \\
\text { xerostomia index } \\
\text { questionnaire was used. }\end{array}$ & $\begin{array}{l}\text { All five patients noticed a } \\
\text { significant improvement } \\
(P \text { value: } 0.002) \text { in } \\
\text { dysphagia and a definite } \\
\text { increase in saliva } \\
\text { production. } \\
\text { No untoward side } \\
\text { effects/complications } \\
\text { were noted in the } \\
\text { patients during or after } \\
\text { completion of treatment. }\end{array}$ \\
\hline $\begin{array}{l}\text { Wong et al. } \\
\text { [93] }\end{array}$ & $\begin{array}{c}\text { Undergone head and } \\
\text { neck radiation } \\
\text { therapy, } N=48\end{array}$ & $\begin{array}{c}\text { ALTENS treatments } \\
\text { were administrated with } \\
\text { a codetron } \\
\text { transcutaneous electrical } \\
\text { nerve stimulation } \\
\text { (TENS) unit and karaya } \\
\text { electrode pads. The } \\
\text { locations of the } \\
\text { acupuncture points used } \\
\text { large intestine } 4 \text { (LI4), } \\
\text { spleen } 6 \text { (SP6), stomach } \\
36 \text { (ST36), and } \\
\text { conception vessel } 24 \\
\text { (CV24). Square pulses of } \\
\text { 250-msec duration were } \\
\text { delivered in trains with a } \\
4 \text { hz repetition rate. One } \\
\text { acupuncture point was } \\
\text { stimulated for } 10 \\
\text { seconds at a time. } \\
\text { Random switching } \\
\text { among electrodes was } \\
\text { used. All patients } \\
\text { received twice weekly } \\
\text { ALTENS sessions (with } \\
20 \text { minutes of } \\
\text { stimulation per session) } \\
\text { for a total of } 24 \text { sessions } \\
\text { given in } 12 \text { weeks. A } \\
\text { maximum of } 2 \text { weeks } \\
\text { without treatment was } \\
\text { allowed, and all } \\
\text { outstanding sessions } \\
\text { were administrated. }\end{array}$ & - & $\begin{array}{l}\text { Preliminary efficacy of } \\
\text { ALTENS treatment was } \\
\text { assessed using the } \\
\text { patient-reported } \\
\text { University of Michigan } \\
\text { Xerostomia-Related } \\
\text { Quality-of-Life-Scale } \\
\text { (XeQOLS). The test was } \\
\text { administrated at } \\
\text { baseline and } 6 \text { months } \\
\text { after study enrollment. }\end{array}$ & $\begin{array}{c}47 \text { patients were } \\
\text { evaluable. } 44 \text { of these } 47 \\
\text { patients ( } 94 \% \text { ) were } \\
\text { successful in complying } \\
\text { with ALTENS } \\
\text { treatments. Of these, } 34 \\
\text { patients ( } 72 \%) \\
\text { completed all treatment } \\
\text { sessions. } \\
\text { Six-month XeQOLS } \\
\text { were available for } 35 \\
\text { patients and indicated } \\
\text { that } 30 \text { patients ( } 86 \%) \\
\text { achieved a positive } \\
\text { treatment response with } \\
\text { a mean } \pm \text { standard } \\
\text { deviation reduction of } \\
\text { 35) } \pm 36,1 \% \text {. There were } \\
\text { no significant acute side } \\
\text { effects associated with } \\
\text { ALTENS treatment. }\end{array}$ \\
\hline
\end{tabular}


TABle 1: Continued.

\begin{tabular}{|c|c|c|c|c|c|}
\hline Reference & Disease & $\begin{array}{c}\text { Stimulation location and } \\
\text { parameters }\end{array}$ & Control group & Evaluation method & Results/conclusion \\
\hline $\begin{array}{l}\text { Strietzel et } \\
\text { al. [94] }\end{array}$ & $\begin{array}{l}\text { Sjögren's syndrome, } \\
\qquad N=114\end{array}$ & $\begin{array}{l}\text { The electrodes directly } \\
\text { contact the oral mucosa } \\
\text { in the mandibular third } \\
\text { molar area, in proximity } \\
\text { to the lingual nerve. }\end{array}$ & $\begin{array}{l}\text { Sham (inactive } \\
\text { stimulation) }\end{array}$ & $\begin{array}{l}\text { Subjective patient } \\
\text { evaluation was } \\
\text { performed. } \\
\text { Intraoral clinical } \\
\text { examination was } \\
\text { performed. } \\
\text { The whole saliva flow } \\
\text { rates were measured. }\end{array}$ & $\begin{array}{c}\text { The active device } \\
\text { performed better than } \\
\text { the sham device for } \\
\text { patient-reported } \\
\text { xerostomia severity } \\
(P<0.002) \text {, xerostomia } \\
\text { frequency }(P<0.05), \\
\text { quality of life } \\
\text { impairment }(P<0.01), \\
\text { and swallowing difficulty } \\
(P<0.02) \text {. At the end of } \\
\text { stage } 2, \text { statistically } \\
\text { significant } \\
\text { improvements were } \\
\text { verified for patient- } \\
\text { reported xerostomia } \\
\text { severity }(P<0.0001), \\
\text { xerostomia frequency } \\
(P<0.0001), \text { oral } \\
\text { discomfort }(P<0.001), \\
\text { speech difficulty } \\
(P<0.02), \text { sleeping } \\
\text { difficulty }(P<0.001) \text {, and } \\
\text { resting salivary flow rate } \\
(P<0.01) .\end{array}$ \\
\hline
\end{tabular}

GenNarino containing an electronic circuit with a microprocessor, a pair of stimulating electrodes, and a $30 \mathrm{~mA} / \mathrm{h}$ battery.

Alajbeg et al. [95]

Xerostomia, $N=94$

The electrodes contact the oral mucosa in the mandibular third molar area, close to the lingual nerve. The electrical current is of low intensity and not felt by the patient.
Improvements achieved at month 5 from baseline were sustained throughout the followup period for the primary outcome, xerostomia severity, and the second outcomes resting whole saliva flow rate,

xerostomia frequency, oral discomfort and difficulties in speech, swallowing and sleeping. No significant side effects were detected.

Acupuncture compared with oral care, produced significant reductions in patients' reports of severe dry mouth with sticky saliva, needing to sip fluids to swallow food and in waking up at night to drink. No significant changes in either stimulated or unstimulated saliva measurements over time. 
TABle 1: Continued.

\begin{tabular}{|c|c|c|c|c|c|}
\hline Reference & Disease & $\begin{array}{c}\text { Stimulation location and } \\
\text { parameters }\end{array}$ & Control group & Evaluation method & Results/conclusion \\
\hline $\begin{array}{l}\text { Pattipati et } \\
\text { al. [97] }\end{array}$ & $\begin{array}{l}\text { Healthy subjects, } \\
\qquad N=90 \text {; } \\
\text { The study was carried } \\
\text { out in three different } \\
\text { age groups } \\
\text { a) Individuals from } 21 \\
\text { to } 35 \text { years } \\
\text { b) } 36-50 \text { years } \\
\text { c) Above } 51 \text { years } \\
\text { In each group, } 30 \\
\text { subjects were taken of } \\
\text { whom } 15 \text { were males } \\
\text { and } 15 \text { were females }\end{array}$ & $\begin{array}{l}\text { Transcutaneous electric } \\
\text { nerve stimulation } \\
\text { (TENS) placement of } \\
\text { pads was approximated } \\
\text { bilaterally over the } \\
\text { parotid glands. The } \\
\text { working parameters of } \\
\text { TENS unit were fixed at } \\
50 \mathrm{~Hz} \text { and } 250 \mu \text { s pulse } \\
\text { rate, and the unit was in } \\
\text { normal mode. }\end{array}$ & - & $\begin{array}{l}\text { The whole saliva flow } \\
\text { rates were measured. }\end{array}$ & $\begin{array}{l}\text { Subjects belonging to } \\
\text { group B were showing a } \\
\text { statistically significant } \\
\text { increase in the duration } \\
\text { of stimulated parotid } \\
\text { salivary flow following } \\
\text { the use of TENS. }\end{array}$ \\
\hline $\begin{array}{l}\text { Vijayan et } \\
\text { al. [98] }\end{array}$ & $\begin{array}{c}\text { Undergone head and } \\
\text { neck radiation } \\
\text { therapy, } N=30\end{array}$ & $\begin{array}{l}\text { The transcutaneous } \\
\text { electrical nerve } \\
\text { stimulation (TENS) } \\
\text { electrode pads were } \\
\text { placed externally on the } \\
\text { skin overlying the } \\
\text { parotid glands using an } \\
\text { extra-oral device, } 1 \mathrm{~cm} \text { in } \\
\text { front of the tragus of the } \\
\text { ear, over the parotid } \\
\text { region with the TENS } \\
\text { unit in the off position. } \\
\text { The TENS machine used } \\
\text { for the study was } \\
\text { MEDIHIGHTEC } 8000 \\
\text { combo } \\
\text { (MEDIHIGHTEC } \\
\text { medical company. Ltd., } \\
\text { Taiwan). The pulse rate } \\
\text { was fixed at } 50 \text { Hz, the } \\
\text { pulse duration was fixed } \\
\text { at } 250 \mu \text { m, the time was } \\
\text { fixed for } 5 \text { min, and the } \\
\text { unit was used in normal } \\
\text { mode. }\end{array}$ & - & $\begin{array}{l}\text { Both stimulated and } \\
\text { unstimulated saliva flow } \\
\text { rates were measured. }\end{array}$ & $\begin{array}{l}29 \text { of } 30 \text { patients showed } \\
\text { increased saliva flow } \\
\text { during stimulation. A } \\
\text { statistically significant } \\
\text { improvement in saliva } \\
\text { production }(P<0.05) \\
\text { during stimulation was } \\
\text { noted. Extra-oral } \\
\text { application of TENS is } \\
\text { effective in increasing the } \\
\text { whole salivary flow in } \\
\text { most of the postradiated } \\
\text { oral cancer patients with } \\
\text { xerostomia. TENS } \\
\text { therapy may be useful as } \\
\text { an effective supportive } \\
\text { treatment modality in } \\
\text { postradiated oral cancer } \\
\text { patients. }\end{array}$ \\
\hline $\begin{array}{l}\text { Zadik et al. } \\
\text { [99] }\end{array}$ & $\begin{array}{l}\text { Oral chronic graft- } \\
\text { versus-host disease } \\
\text { (cGVHD), } N=6\end{array}$ & $\begin{array}{l}\text { The electrodes directly } \\
\text { contact the oral mucosa } \\
\text { in the mandibular third } \\
\text { molar area, in proximity } \\
\text { to the lingual nerve. }\end{array}$ & - & $\begin{array}{l}\text { Clinical examination } \\
\text { was performed. } \\
\text { Both stimulated and } \\
\text { unstimulated saliva flow } \\
\text { rates were measured. }\end{array}$ & $\begin{array}{l}\text { Two patients developed } \\
\text { mild mucosal lesions in } \\
\text { areas in contact with the } \\
\text { GenNarino. However, } \\
\text { only one of them had a } \\
\text { change in the national } \\
\text { institutes of health (NIH) } \\
\text { score for oral cGVHD. } \\
\text { The unstimulated and } \\
\text { stimulated salivary flow } \\
\text { increased in } 4 \text { out of the } 5 \\
\text { patients included in the } \\
\text { analysis. }\end{array}$ \\
\hline
\end{tabular}


Table 1: Continued.

\begin{tabular}{|c|c|c|c|c|c|}
\hline Reference & Disease & $\begin{array}{c}\text { Stimulation location and } \\
\text { parameters }\end{array}$ & Control group & Evaluation method & Results/conclusion \\
\hline $\begin{array}{l}\text { Aggarwal et } \\
\text { al. [100] }\end{array}$ & $\begin{array}{l}\text { Healthy subjects, } \\
\qquad N=80\end{array}$ & $\begin{array}{l}\text { The TENS unit was } \\
\text { anlaya MedIns - AMS- } \\
902 \text {. The surface } \\
\text { electrode pads were } \\
\text { placed externally on the } \\
\text { skin, overlying the } \\
\text { parotid glands. The unit } \\
\text { was preset at a frequency } \\
\text { of } 100 \mathrm{~Hz} \text { and a pulse } \\
\text { width of } 100-150 \mu \mathrm{s} \\
\text { between the } \\
\text { measurement of } \\
\text { unstimulated and } \\
\text { stimulated saliva. Then, } \\
\text { the TENS unit was } \\
\text { activated and the } \\
\text { amplitude was gradually } \\
\text { increased to a maximum } \\
\text { tolerable level for } \\
\text { patients. }\end{array}$ & - & $\begin{array}{l}\text { Both stimulated and } \\
\text { unstimulated saliva flow } \\
\text { rates were measured. }\end{array}$ & $\begin{array}{c}\text { The mean unstimulated } \\
\text { flow rate was } 1.25 \mathrm{ml} / \\
\text { min, the mean } \\
\text { stimulated salivary flow } \\
\text { rate was } 1,41 \mathrm{ml} / \mathrm{min} .65 \\
\text { of } 80 \text { subjects } \\
\text { demonstrate an increase } \\
\text { in salivary flow rate on } \\
\text { application of TENS. } 12 \\
\text { subjects showed no } \\
\text { increase in the salivation, } \\
\text { while three subjects } \\
\text { showed a decrease in the } \\
\text { salivary flow. These } \\
\text { findings showed an } \\
\text { approximately } 13 \% \\
\text { (0.16 ml/min) increase in } \\
\text { the mean salivary flow } \\
\text { rate on application of } \\
\text { TENS. }\end{array}$ \\
\hline $\begin{array}{l}\text { Lakshman } \\
\text { et al. [101] }\end{array}$ & $\begin{array}{c}\text { Undergone head and } \\
\text { neck radiation } \\
\text { therapy, } N=40\end{array}$ & $\begin{array}{l}\text { TENS model-NS electro } \\
\text { pulse that generates } \\
\text { current through AC at a } \\
\text { continuous frequency of } \\
500 \mathrm{~Hz} \text { with a sweep of } \\
0.5-2 \mathrm{~Hz} \text {. The electrodes } \\
\text { are placed externally on } \\
\text { the skin overlying the } \\
\text { parotid glands. }\end{array}$ & $\begin{array}{l}\text { Healthy subjects, } \\
\qquad N=10\end{array}$ & $\begin{array}{l}\text { Both stimulated and } \\
\text { unstimulated saliva flow } \\
\text { rates were measured. }\end{array}$ & $\begin{array}{l}\text { The data analysis } \\
\text { revealed that control and } \\
\text { S1B group showed } \\
\text { increased salivary flow } \\
\text { rate after stimulation by } \\
\text { TENS therapy, compared } \\
\text { with the unstimulated } \\
\text { salivary flow, whereas in } \\
\text { S1A and S1B group it was } \\
\text { found to be statistically } \\
\text { nonsignificant. }\end{array}$ \\
\hline
\end{tabular}


TABle 1: Continued.

\begin{tabular}{|c|c|c|c|c|c|}
\hline Reference & Disease & $\begin{array}{l}\text { Stimulation location and } \\
\text { parameters }\end{array}$ & Control group & Evaluation method & Results/conclusion \\
\hline $\begin{array}{l}\text { Wong et al. } \\
{[102]}\end{array}$ & $\begin{array}{c}\text { Undergone head and } \\
\text { neck radiation } \\
\text { therapy, } N=148\end{array}$ & $\begin{array}{c}\text { ALTENS were } \\
\text { administrated with a } \\
\text { codetron TENS unit and } \\
\text { karaya electrode pads. } \\
\text { Bilateral acupuncture } \\
\text { points - SP6, ST36, LI4- } \\
\text { using uncommon } \\
\text { electrodes and CV24 } \\
\text { using the common } \\
\text { electrode were } \\
\text { stimulated. Sequences of } \\
250 \text { millisecond square } \\
\text { pulses with a } 4 \text { Hz } \\
\text { repetition rate were } \\
\text { delivered. Each } \\
\text { acupuncture point, } \\
\text { except CV24, was } \\
\text { stimulated for } 10 \\
\text { seconds at a time; CV24, } \\
\text { the site for the common } \\
\text { electrode, was stimulated } \\
\text { throughout the } \\
\text { treatment session. } \\
\text { Stimulation intensity } \\
\text { was adjusted to produce } \\
\text { a deep strong aching } \\
\text { sensation at each } \\
\text { acupuncture point. All } \\
\text { patients were to receive } \\
24 \text { ALTENS sessions ( } 20 \\
\text { minutes each, } 2 \text { sessions } \\
\text { per week), for } 12 \text { weeks. } \\
\text { Pilocarpine treatment } \\
\text { started within } 14 \text { days of } \\
\text { enrollment. Patient } \\
\text { received } 5 \text { mg } \\
\text { pilocarpine orally } 3 \\
\text { times daily for } 12 \text { weeks } \\
\text { and then stopped for the } \\
\text { rest of the study. }\end{array}$ & $\begin{array}{l}\text { Randomized study } \\
\text { that compared } \\
\text { ALTENS with } \\
\text { prilocarpine (PC) } \\
\text { for relieving } \\
\text { radiation-induced } \\
\text { xerostomia. } \\
\text { Patients: (73 in the } \\
\text { pilocarpine group } \\
\text { and } 75 \text { in the } \\
\text { ALTENS group) }\end{array}$ & $\begin{array}{l}\text { The primary endpoint } \\
\text { was the change in the } \\
\text { University of Michigan } \\
\text { Xerostomia-Related } \\
\text { Quality of Life scale } \\
\text { (XeQOLS) scores from } \\
\text { baseline to } 9 \text { months } \\
\text { from randomization } \\
\text { (MFR). Secondary } \\
\text { endpoints included } \\
\text { basal and citric-acid- } \\
\text { primed whole salivary } \\
\text { production (WSP), } \\
\text { ratios of positive } \\
\text { responders (defined as } \\
\text { patients with } 20 \% \\
\text { reduction in overall } \\
\text { radiation-induced } \\
\text { xerostomia symptom } \\
\text { burden), and the } \\
\text { presence of adverse } \\
\text { events based on the } \\
\text { common terminology } \\
\text { criteria for adverse } \\
\text { events version } 3 . \text { An } \\
\text { intention-to-treat } \\
\text { analysis was conducted. }\end{array}$ & $\begin{array}{l}\text { Only } 96 \text { patients } \\
\text { completed the required } \\
\text { XeQOLS and were } \\
\text { evaluable at } 9 \text { MFR } \\
\text { (representing merely } \\
68.6 \% \text { statistical power). } \\
\text { Seventy-six patients were } \\
\text { evaluable at } 15 \text { MFR. The } \\
\text { median change in the } \\
\text { overall XeQOLS in } \\
\text { ALTENS and PC groups } \\
\text { at } 9 \text { and } 15 \text { MFR were } \\
0.53 \text { and } 0.27 \text { (PZ.45) } \\
\text { and } 0.6 \text { and } 0.47 \text { (PZ.21). } \\
\text { The corresponding } \\
\text { percentages of positive } \\
\text { responders were } 81 \% \text { and } \\
72 \% \text { (PZ.34) and } 83 \% \\
\text { and } 63 \% \text { (PZ.04). } \\
\text { Changes in WSP were } \\
\text { not significantly different } \\
\text { between the groups. } \\
\text { Grade } 3 \text { or less adverse } \\
\text { events, mostly consisting } \\
\text { of grade } 1 \text {, developed in } \\
20.8 \% \text { of patients in the } \\
\text { ALTENS group and in } \\
61.6 \% \text { of the PC group. }\end{array}$ \\
\hline
\end{tabular}


TABle 1: Continued.

\begin{tabular}{|c|c|c|c|c|c|}
\hline Reference & Disease & $\begin{array}{l}\text { Stimulation location and } \\
\text { parameters }\end{array}$ & Control group & Evaluation method & Results/conclusion \\
\hline $\begin{array}{l}\text { Hasegawa } \\
\text { et al. [103] }\end{array}$ & $\begin{array}{l}\text { Three groups: } 20 \\
\text { young adults, } 19 \text { older } \\
\text { adults, and } 21 \text { patients } \\
\text { with dry mouth, } \\
\quad N=60\end{array}$ & $\begin{array}{l}\text { Used IFCS with a beat } \\
\text { frequency of } 50 \mathrm{~Hz} \text { and a } \\
\text { carrier frequency of } \\
2000 \mathrm{~Hz} \text {. The signal type } \\
\text { was bipolar. } \\
\text { Two independent pairs } \\
\text { of electrodes were placed } \\
\text { at bilateral } \\
\text { submandibular regions } \\
\text { symmetrically, targeting } \\
\text { both the submandibular } \\
\text { and sublingual glands. }\end{array}$ & - & $\begin{array}{l}\text { Secreted saliva was } \\
\text { collected by using } \\
\text { salivette cotton rolls for } \\
15 \text { minutes, either with } \\
\text { or without interferential } \\
\text { current stimulation } \\
\text { (IFCS). Patients were } \\
\text { randomly chosen to } \\
\text { receive IFCS. Each } \\
\text { subject rated pain and } \\
\text { discomfort on the visual } \\
\text { analog scale (VAS) after } \\
\text { each experiment. Saliva } \\
\text { chromograin A levels } \\
\text { were measured as a } \\
\text { stress marker. To } \\
\text { compare data between } \\
\text { conditions with or } \\
\text { without IFCS, a two- } \\
\text { sample Student's } t \text {-test } \\
\text { analysis was performed. }\end{array}$ & $\begin{array}{l}\text { Saliva flow was slightly } \\
\text { increased in those in the } \\
\text { dry mouth group } \\
\text { receiving IFCS compared } \\
\text { with those who did not } \\
\text { receive IFCS } \\
\text { (approximately 130\%). } \\
\text { However, no such } \\
\text { difference was found in } \\
\text { the young and older } \\
\text { adult groups. There was } \\
\text { no significant difference } \\
\text { in the VAS values of pain } \\
\text { and discomfort or in the } \\
\text { stress marker levels } \\
\text { between patient who } \\
\text { received or did not } \\
\text { receive IFCS in the three } \\
\text { groups. IFCS delivered to } \\
\text { submandibular and } \\
\text { sublingual glands may } \\
\text { promote saliva secretion } \\
\text { in persons who suffer } \\
\text { from dry mouth in a } \\
\text { manner that does not } \\
\text { induce pain or physical } \\
\text { stress. }\end{array}$ \\
\hline
\end{tabular}

The mean salivary flow rates at baseline were statistically significantly lower in group 1 than group 2. There was a

The TENS unit was ultrasonic TENS. The technical specifications of the TENS unit were $220 \mathrm{~V}, \mathrm{~A} / \mathrm{C} 50 \mathrm{~Hz}$,

50 postmenopausal females with or without dryness

Divided into 2 groups of 25 each; (1)

Konidena et al. [104] postmenopausal women with oral dryness and (2) postmenopausal women without oral dryness
$0-100 \mathrm{~mA}$ at $1 \mathrm{k}$ load, biphasic wave form, available in pulsed/ continuous form, and 2 intensities, I and II. The electrode of TENS unit was then placed vertically, externally on the skin overlying the parotid gland, in the preauricular area

bilaterally, $1 \mathrm{~cm}$ in front of the tragus area.
Unstimulated whole saliva was collected by the low forced splitting method. External salivary secretion of parotid glands by electrodes of TENS unit was done and sialometry was repeated. The salivary flow rates were compared within both groups before and after stimulation and between two groups. mean increase of $0.33 \mathrm{ml}$ and $0.46 \mathrm{ml}$ with TENS stimulation in the two groups, respectively.

Postmenopausal women with perception of oral dryness had lower salivary flow rates. $90 \%$ of the subjects, irrespective of oral dryness status, responded to TENS therapy. TENS

stimulation resulted in a statistically significant increase in the quantity of whole saliva flow rate in postmenopausal women with or without dryness. 
TABle 1: Continued.

\begin{tabular}{|c|c|c|c|c|}
\hline Reference & Disease & $\begin{array}{c}\text { Stimulation location and } \\
\text { parameters }\end{array}$ & Control group & Evaluation method \\
\hline $\begin{array}{l}\text { Aparna et } \\
\text { al. [105] }\end{array}$ & $\begin{array}{c}\text { Subjects with } \\
\text { complaint of } \\
\text { hyposalivation, } N=25\end{array}$ & $\begin{array}{l}\text { TENS units were placed } \\
\text { over the parotid region. } \\
\text { The intensity control } \\
\text { switch was adjusted for } \\
\text { patient's comfort. The } \\
\text { intensity was turned up } 1 \\
\text { increment at a time at } 5 \mathrm{~s} \\
\text { intervals until the } \\
\text { optimal intensity level } \\
\text { was reached. }\end{array}$ & - & $\begin{array}{l}\text { Unstimulated saliva was } \\
\text { collected using modified } \\
\text { carlson crittenden cup } \\
\text { placed over the } \\
\text { Stenson's duct } \\
\text { bilaterally for } 5 \text { min and } \\
\text { measured. A paired } t \text { - } \\
\text { test, evaluating mean } \\
\text { changes in stimulated } \\
\text { versus unstimulated } \\
\text { salivary flow rates. }\end{array}$ \\
\hline
\end{tabular}

Tabletop TENS unit with surface electrode pads were placed externally in the skin overlying the parotid glands (anteroposteriorly between the tragus of the ear and the midmasseter region and

Dyasnoor et al. [106]

Diabetes mellitus patients with xerostomia, $N=40$

\section{superoinferiorly between} the region of the head of the mandible and above the lower boarder of the mandible. The pulse rate was fixed at $50 \mathrm{~Hz}$, and the intensity was gradually increased to a maximum tolerable level for each patient.
Unstimulated saliva through the "low forced splitting" method and stimulated saliva collecting using TENS were assessed and compared. Long-term effects of TENS application were evaluated by recalling the patient 24 hours later.

Results/conclusion

Significant increase in parotid salivary flow rates (SFR) in 19 of 25 patients after TENS. Males showed more salivary secretion compared to females. TENS showed to be effective in increasing the SF rate in hyposalivatory patients with residual saliva.

A statistically significant increase in stimulated whole saliva after TENS application in continuous mode $(P<0.001)$ was

demonstrated compared with the unstimulated saliva, especially in xerostomia patients with diabetes. Burst mode inferred a statistically significant decrease in salivary flow $(P<0.001)$.

In patients with diabetes with xerostomia and hyposalivation, TENS was highly effective in stimulating whole salivary flow.

The most prevalent region for RT was the oropharynx $(80 \%$ of cases). The mean dose used in RT was $64,6 \pm 7,24$ Gy. After TENS, salivary flow increased significantly $(P=0.0051)$ from

TENS was adjusted with $50 \mathrm{~Hz}$ of frequency and $250 \mu$ s of pulse width intensity was adjusted over a 20 -minute period according to maximum tolerance. The electrodes were placed bilaterally on the region of the salivary glands.
Evaluation of the salivary flow was performed through sialometry before and immediately after application of TENS.
$0.05 \mathrm{~mL} / \mathrm{min}$ to $0.01 \mathrm{~mL} /$ min. The response to TENS was directly correlated with the intensity of the tolerated electric current $(r=0.553 ; P=0.032)$ and the dose used in RT $(r=-0.514 ; P=0.050)$.

TENS was able to increase the salivary flow rate of patients with RTinduced hyposalivation. 
TABle 1: Continued.

\begin{tabular}{|c|c|c|c|c|c|}
\hline Reference & Disease & $\begin{array}{l}\text { Stimulation location and } \\
\text { parameters }\end{array}$ & Control group & Evaluation method & Results/conclusion \\
\hline $\begin{array}{l}\text { Wolff et al. } \\
\text { [108] }\end{array}$ & $\begin{array}{l}\text { Severe xerostomia, no } \\
\text { collectable saliva, } N=3\end{array}$ & $\begin{array}{l}\text { GenNarino contains an } \\
\text { electronic circuit with a } \\
\text { microprocessor, a pair of } \\
\text { stimulation electrodes, } \\
\text { and two } 3 \mathrm{~V} 30 \mathrm{mAmp} / \mathrm{h} \\
\text { batteries. The electrodes } \\
\text { contact the oral mucosa } \\
\text { in the mandibular third } \\
\text { molar area, close to the } \\
\text { lingual nerve on one } \\
\text { side. The electrical } \\
\text { stimulation is of low } \\
\text { intensity and not felt by } \\
\text { the patient. In this trial, } \\
\text { the stimulation signals } \\
\text { were pulse-trains at } 5 \mathrm{~Hz} \text {, } \\
\text { biphasic, at rectangular } \\
\text { pulses of } 1 \text { mSec, with an } \\
\text { output of } 150 \mu \mathrm{A} \text {. }\end{array}$ & - & $\begin{array}{l}\text { The whole saliva flow } \\
\text { rates were measured. }\end{array}$ & $\begin{array}{l}\text { All the three subjects } \\
\text { developed the capacity to } \\
\text { spit saliva, not only in } \\
\text { direct response to the } \\
\text { electrostimulation but } \\
\text { also after free intervals } \\
\text { without } \\
\text { electrostimulation. In } \\
\text { addition, their symptoms } \\
\text { of dry mouth severity } \\
\text { and frequency improved. } \\
\text { For all three subjects, no } \\
\text { significant changes in the } \\
\text { vital signs and in the oral } \\
\text { mucosal status were } \\
\text { observed. }\end{array}$ \\
\hline
\end{tabular}

After 6 TENS sessions were completed, whole salivary flow rates increased stably until the end of 9 TENS sessions for the treatment group.

Yang et al. Hemodialysis patients, $250 \mu$ s and $50 \mathrm{~Hz}$ TENS [109] $N=80$ program were used.
Control group received a $50 \mu \mathrm{s}$,

Whole salivary flow rate and dry mouth intensity were measured totally five times for both $2 \mathrm{~Hz}$ TENS at acupoints ST6 and TE17 three times a week for 3 weeks groups, at pretreatment, after 3, 6, and 9 TENS sessions, and one week after the treatment was completed.
In the follow-up week

after treatment, there was significant increase as well. However,

significant improvement in dry mouth intensity was observed at all posttests than that at pretreatment in both groups. Whole salivary flow rates and dry mouth intensity improving were only observed during and one week after the TENS sessions. 
TABle 1: Continued.

\begin{tabular}{|c|c|c|c|c|c|}
\hline Reference & Disease & $\begin{array}{c}\text { Stimulation location and } \\
\text { parameters }\end{array}$ & Control group & Evaluation method & Results/conclusion \\
\hline
\end{tabular}

Although no changes were observed in the control group for SSF at any timepoints, TENS group showed a progressive increase in SSF from the third

TENS group $(n=37)$ received 8 sessions $(20$ minutes each) delivered twice a week for four weeks. The electrodes Paim et al. Patients with were attached over the [110] hyposalivation, $N=68$ skin covering the salivary glands. The electric pulse was adjusted at a frequency of $50 \mathrm{hz}$, pulse width of $250 \mu \mathrm{s}$. and as intense as tolerated.
SSF was evaluated through sialometry.

Participants in the Self-perception of control group $(N=31)$ received habitual care salivary flow (SPSF) and quality of life (QL) was evaluated prior to, during, and at 1,3 , and 6 months after treatment. session until the end of the treatment. Significant improvements were also found in SPSF, especially when the SSF reached values $\geq 0.7 \mathrm{~mL} /$ minute.

The most expressive results were evident at 6 months after treatment so that SSF, SPSF, and QL remained significantly higher $(F=9.5, P=0.0001$;

$H=143.77, P<0.0001$; $\chi 2=9.162, P=0.02$, respectively). TENS was

effective at improving hyposalivation.

Randomly distributed to one experimental group,

Diabetes mellitus type receiving one extra-oral $\begin{array}{ll}\text { Ali et al. } & 2 \text { patients with } \\ \text { hyposalivation, }\end{array}$ $N=100$, age range from 43 to 76 years

5 minutes TENS session, applied bilaterally on skin over parotid gland with frequency $50 \mathrm{~Hz}$ and pulse duration $250 \mu$ s.

Patients treated with radiotherapy with or without chemotherapy

Iovoli et al. for head and neck 2020 [112] cancer $(N=30)$, with at least grade 1 or 2 symptomatic dry mouth
Patients randomly assigned to receive ALTENS four-times weekly for 6 weeks or two times weekly for 12 weeks.
Unstimulated saliva was collected for 5 minutes immediately after the session, using the low forced spitting method. Stimulated saliva was collected during TENS application in graduated test tube. administered at $6,9,15$, and 21 months from the This study demonstrates start of ALTENS treatment. A linear model was used to model the overall

XeQoLS score at the 15month endpoint. that both ALTENS regimens are safe, well tolerated, and appear to be equally effective.
90 out of 100 patients responded positively to

TENS by increasing salivary volume and flow rate.
Participants examined under three conditions of NMES: Sensory threshold plus $75 \%$ of the difference between sensory and pain

Electrical stimulation was applied at constant

Koike et al. Healthy adults [113] $\quad(N=20)$ strength for 60 minutes to the suprahyoid muscles using VitalStim ${ }^{\circledR}$. thresholds (75\% stim), SensoryStim, and sham. Saliva collections, using a 10-min spitting method, were

performed seven times:

Before stimulation (S1), during stimulation

(S2-S6), and 5 min after stimulation ended (S7).
Increase in saliva flow was promoted after NMES. Therefore, NMES may have effects on patients with xerostomia. 


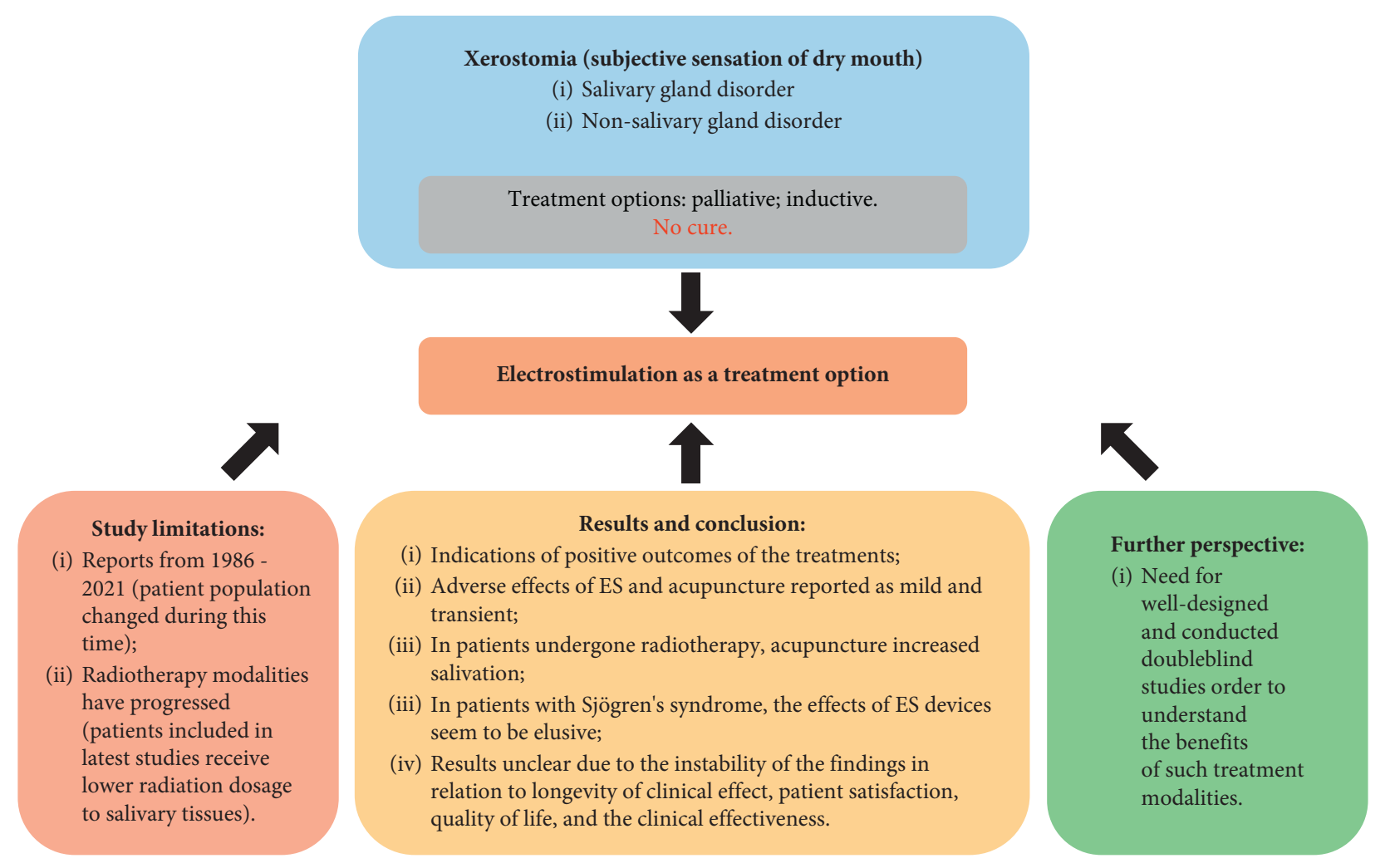

Figure 1: Main conclusions of the study: schematic representation.

promising therapy for either preserving or restoring vision in several retinal and optic nerve diseases [76].

Electrostimulation of the salivary glands and acupuncture aim to increase the production of saliva. In ES, a handheld battery-operated device is used to provide an electrical stimulus to the hard palate or dorsum of the tongue. Alternatively, a transcutaneous electrical nerve stimulation (TENS) device may be utilized by connecting the electrodes to the skin and may be used either in clinical setting or in the patient's home. Acupuncture and ES have been shown to exert both clinical and biological effect with regard to the treatment of dry mouth $[44,77]$. It has been demonstrated that application of electrical impulses to one or more arms of the salivary reflex arch may result in increased secretion of saliva [43]. ES of the lingual nerve, i.e., the efferent trigeminal fibers, may stimulate the sublingual and submandibular glands to increase salivation [44]. Regarding acupuncture, it is suggested to induce physiological effects such as increased peripheral blood flow and stimulation of the autonomic nervous system, which in turn may lead to increased production of saliva [78].

The beneficial effects of noninvasive ES in patients with xerostomia due to Sjögren's syndrome and radiation therapy have been reported previously, which sparked a research interest in the effects of ES in clinical studies for treating dry mouth [79]. The methods include therapies such as acupuncture and acupuncture-like TENS [80], both of which focus on specific points in and around the head and neck region and aim to stimulate the parasympathetic innervation of salivary glands. The first study on acupuncture for the treatment of xerostomia was reported in 1981 [81], and since then, many studies using this method have reported an increase in salivary flow rate in both healthy and diseased patients (Table 1). Blom and collaborators showed that the effects of acupuncture resulted in relief for patients who have undergone head and neck radiation therapy and in individuals with Sjogren's syndrome. The study also demonstrated that the relief reported by the patients continued for up to six months posttreatment [86]. Another study reported that the use of acupuncture in patients with xerostomia increased the amount of calcitonin gene-related peptide in saliva [85], a protein known to positively affect the salivary flow and provide beneficial trophic effects on the oral mucosa. Three other controlled trials studied the therapeutic efficacy of acupuncture in patients that exhibited radiationinduced xerostomia $[84,90,96]$; however, they all exhibited the high risk of bias due to the overall poor reporting of blinding and randomization. A single-blinded study showed no significant difference in salivary flow in the active acupuncture group compared with control patients (sham acupuncture) after six weeks of twice-a-week acupuncture treatment [90]. Furthermore, Simcock et al. investigated the effects of eight weeks of once-a-week acupuncture compared to the effects of the use of artificial saliva, and they reported an improvement in xerostomia symptoms in acupuncture patients compared to controls [96]. However, in this study, the magnitude of the improvement, as well as clinical significance, was indistinct. No statistical difference in salivary 
flow between individuals randomized to twelve weeks of real or sham acupuncture was also reported by Blom et al. in 1996 [84]. A recent study from 2019, a randomized clinical trial, found that true acupuncture resulted in significantly fewer and less severe symptoms one year after treatment vs standard care control and sham acupuncture in radiationinduced xerostomia patients, although authors reported inconsistence in results with sham acupuncture and suggested further research to confirm their findings clinically [114].

Acupuncture-like TENS perform the same objective as acupuncture without using the needles and has been shown to be effective. Wong and colleagues utilized a method termed Codetron to deliver electric nerve stimulation twice a week for six weeks to patients with symptomatic xerostomia resulting from radiation therapy [87]. They evaluated the residual salivary function and the results demonstrated statistically significant improvements in both subjective complaints of dry mouth and salivary flow rates for up to six months after treatment [81]. Another study investigated the effects of twelve weeks of acupuncture-like TENS (twice per week for a total of 24 sessions of $20 \mathrm{~min}$ each) versus pilocarpine and showed no significant difference in salivary flow or xerostomia-related quality of life scale score between the groups [102]. However, this study lacked the detailed information regarding the blinding, sequence generation, and allocation concealment.

\section{Conclusion and Future Perspectives}

Xerostomia, a symptom of dry mouth, is a condition that at present has no definitive means for treatment. Several inductive and palliative treatment approaches appear to be effective for reducing the morbidity associated with xerostomia. Most of the available treatment options are quite simply transient and are not considered to be an optimal treatment option. The present review has its limitations. The studies included in the work were reported between 1981 and 2021 and the patient population has changed during this time. Furthermore, the radiotherapy modalities have also progressed, where patients included in the most recent studies receive lower radiation dosage to salivary tissues.

So far, there is poor evidence on the effects of any of the interventions included in this review on patients with xerostomia. A number of patients with xerostomia show some indications of positive outcomes of these treatments, and the adverse effects of both ES and acupuncture have been reported as mild and transient. In patients who have undergone radiotherapy, the acupuncture is shown to increase salivation. However, in patients with Sjogren's syndrome, the effects of ES devices seem to be elusive. Moreover, due to the instability of the findings in relation to longevity of clinical effect, patient satisfaction, quality of life, and the clinical effectiveness of such treatments, the results remain unclear. Further well-designed and conducted double-blind studies are warranted in order to understand the benefits of these treatment modalities (Figure 1).

\section{Abbreviations}

TENS: Transcutaneous electrical nerve stimulation

RT: Radiotherapy

SFR: $\quad$ Salivary flow rate

IR: Infrared

ALTENS: Acupuncture-like transcutaneous electrical nerve stimulation

VAS: Visual analog scale

SSF: $\quad$ Stimulated salivary flow

SPSF: $\quad$ Self-perception of salivary flow

QL: $\quad$ Quality of life

XeQoLS: Xerostomia-related quality-of-life scale

cGVHD: Chronic graft-versus-host-disease

PC: $\quad$ Pilocarpine

WSP: Whole salivary production

MFR: $\quad$ Months from randomization

IFCS: Interferential current stimulation

LI4: $\quad$ Large intestine 4

SP6: $\quad$ Spleen 6

ST36: Stomach 36

CV24: Conception vessel 24

NMES: Neuromuscular electrical stimulation.

\section{Conflicts of Interest}

The authors declare no conflicts of interest.

\section{Authors' Contributions}

AT, AM, MH, TPU, and AS equally contributed to the conception, design, data acquisition, and interpretation, and drafted and critically revised the manuscript. All authors gave their final approval and agreed to be accountable for any aspect of the present review.

\section{References}

[1] S. P. Humphrey and R. T. Williamson, "A review of saliva: normal composition, flow, and function," The Journal of Prosthetic Dentistry, vol. 85, no. 2, pp. 162-169, 2001.

[2] I. D. Mandel, "The functions of saliva," Journal of Dental Research, vol. 66, no. 1_suppl, pp. 623-627, 1987.

[3] A. Pedersen, A. Bardow, S. B. Jensen, and B. Nauntofte, "Saliva and gastrointestinal functions of taste, mastication, swallowing and digestion," Oral Diseases, vol. 8, no. 3, pp. 117-129, 2002.

[4] L. A. Tabak, "In defense of the oral cavity: structure, biosynthesis, and function of salivary mucins," Annual Review of Physiology, vol. 57, no. 1, pp. 547-564, 1995.

[5] W. M. Edgar, "Saliva: its secretion, composition and functions," British Dental Journal, vol. 172, no. 8, pp. 305-312, 1992.

[6] S. Watanabe and C. Dawes, "The effects of different foods and concentrations of citric acid on the flow rate of whole saliva in man," Archives of Oral Biology, vol. 33, no. 1, pp. 1-5, 1988.

[7] R. Holland and B. Matthews, "Conditioned reflex salivary secretion in man," Archives of Oral Biology, vol. 15, no. 8, pp. 761-767, 1970. 
[8] G. N. Jenkins and C. Dawes, "The psychic flow of saliva in man," Archives of Oral Biology, vol. 11, no. 11, pp. 1203-1204, 1966.

[9] V. Lee and R. Linden, "An olfactory-submandibular salivary reflex in humans," Experimental Physiology, vol. 77, no. 1, pp. 221-224, 1992.

[10] A. M. L. Pedersen, C. E. Sørensen, G. B. Proctor, G. H. Carpenter, and J. Ekström, "Salivary secretion in health and disease," Journal of Oral Rehabilitation, vol. 45, no. 9, pp. 730-746, 2018.

[11] L. Zheng, Y. J. Seon, J. McHugh, S. Papagerakis, and P. Papagerakis, "Clock genes show circadian rhythms in salivary glands," Journal of Dental Research, vol. 91, no. 8, pp. 783-788, 2012.

[12] S. Papagerakis, L. Zheng, S. Schnell et al., "The circadian clock in oral health and diseases," Journal of Dental Research, vol. 93, no. 1, pp. 27-35, 2014.

[13] S. Ericson, "The variability of the human parotid flow rate on stimulation with citric acid, with special reference to taste," Archives of Oral Biology, vol. 16, no. 1, pp. 9-IN1, 1971.

[14] H. Inoue, K. Ono, W. Masuda et al., "Gender difference in unstimulated whole saliva flow rate and salivary gland sizes," Archives of Oral Biology, vol. 51, no. 12, pp. 1055-1060, 2006.

[15] K. Ono, H. Inoue, W. Masuda et al., "Relationship of chewing-stimulated whole saliva flow rate and salivary gland size," Archives of Oral Biology, vol. 52, no. 5, pp. 427-431, 2007.

[16] C. Dawes, "Physiological factors affecting salivary flow rate, oral sugar clearance, and the sensation of dry mouth in man," Journal of Dental Research, vol. 66, no. 1_suppl, pp. 648-653, 1987.

[17] J. J. Napeñas, M. T. Brennan, and P. C. Fox, "Diagnosis and treatment of xerostomia (dry mouth)," Odontology, vol. 97, no. 2, pp. 76-83, 2009.

[18] V. Visvanathan and P. Nix, "Managing the patient presenting with xerostomia: a review," International Journal of Clinical Practice, vol. 64, no. 3, pp. 404-407, 2010.

[19] M. Hopcraft and C. Tan, "Xerostomia: an update for clinicians," Australian Dental Journal, vol. 55, no. 3, pp. 238-244, 2010.

[20] S. R. Porter, C. Scully, and A. M. Hegarty, "An update of the etiology and management of xerostomia," Oral Surgery, Oral Medicine, Oral Pathology, Oral Radiology and Endodontics, vol. 97, no. 1, pp. 28-46, 2004.

[21] R. J. Billings, H. M. Proskin, and M. E. Moss, "Xerostomia and associated factors in a community-dwelling adult population," Community Dentistry and Oral Epidemiology, vol. 24, no. 5, pp. 312-316, 1996.

[22] O. D. Schein, M. C. Hochberg, B. Muñoz et al., "Dry eye and dry mouth in the elderly," Archives of Internal Medicine, vol. 159, no. 12, pp. 1359-1363, 1999.

[23] H. Mese and R. Matsuo, "Salivary secretion, taste and hyposalivation," Journal of Oral Rehabilitation, vol. 34, no. 10, pp. 711-723, 2007.

[24] F. Femiano, A. Lanza, C. Buonaiuto et al., "Oral manifestations of adverse drug reactions: guidelines," Journal of the European Academy of Dermatology and Venereology, vol. 22, no. 6, pp. 681-691, 2008.

[25] I. von Bültzingslöwen, "Salivary dysfunction associated with systemic diseases: systematic review and clinical management recommendations," Oral Surgery, Oral Medicine, Oral Pathology, Oral Radiology and Endodontics, vol. 103, pp. S57.e1-S57.e15, 2007.
[26] H. Mortazavi, M Baharvand, A Movahhedian, M Mohammadi, and A Khodadoustan, "Xerostomia due to systemic disease: a review of 20 conditions and mechanisms," Annals of Medical and Health Sciences Research, vol. 4, no. 4, pp. 503-510, 2014.

[27] K. R. Bhattarai, R. Junjappa, M. Handigund, H.-R. Kim, and H.-J. Chae, "The imprint of salivary secretion in autoimmune disorders and related pathological conditions," Autoimmunity Reviews, vol. 17, no. 4, pp. 376-390, 2018.

[28] P. Pérez, Y.-J. Kwon, C. Alliende et al., "Increased acinar damage of salivary glands of patients with Sjögren's syndrome is paralleled by simultaneous imbalance of matrix metalloproteinase 3/tissue inhibitor of metalloproteinases 1 and matrix metalloproteinase 9/tissue inhibitor of metalloproteinases 1 ratios," Arthritis and Rheumatism, vol. 52, no. 9, pp. 2751-2760, 2005.

[29] K. Fejfer, P Buczko, M Niczyporuk et al., "Oxidative modification of biomolecules in the nonstimulated and stimulated saliva of patients with morbid obesity treated with bariatric surgery," BioMed Research International, vol. 2017, Article ID 4923769, 2017.

[30] M. Maciejczyk, K. Taranta-Janusz, A. Wasilewska, A. Kossakowska, and A. Zalewska, "A case-control study of salivary redox homeostasis in hypertensive children. Can salivary uric acid be a marker of hypertension?" Journal of Clinical Medicine, vol. 9, no. 3, p. 837, 2020.

[31] R. L. Xiang, Y. Huang, Y. Zhang et al., “Type 2 diabetesinduced hyposalivation of the submandibular gland through PINK1/Parkin-mediated mitophagy," Journal of Cellular Physiology, vol. 235, no. 1, pp. 232-244, 2020.

[32] T. Molania, M. Alimohammadi, O. Akha, J. Mousavi, R. Razvini, and M. Salehi, "The effect of xerostomia and hyposalivation on the quality of life of patients with type II diabetes mellitus," Electronic Physician, vol. 9, no. 11, pp. 5814-5819, 2017.

[33] M. Maciejczyk, J. Szulimowska, K. Taranta-Janusz, A. Wasilewska, and A. Zalewska, "Salivary gland dysfunction, protein glycooxidation and nitrosative stress in children with chronic kidney disease," Journal of Clinical Medicine, vol. 9, no. 5, p. 1285, 2020.

[34] A. Klimiuk, A. Zalewska, M. Knapp, R. Sawicki, J. R. Ładny, and M. Maciejczyk, "Salivary gland dysfunction in patients with chronic heart failure is aggravated by nitrosative stress, as well as oxidation and glycation of proteins," Biomolecules, vol. 11, no. 1, p. 119, 2021.

[35] P. Żukowski, M. Maciejczyk, and D. Waszkiel, "Sources of free radicals and oxidative stress in the oral cavity," Archives of Oral Biology, vol. 92, pp. 8-17, 2018.

[36] A. Zalewska, M. Maciejczyk, J. Szulimowska, M. Imierska, and A. Błachnio-Zabielska, "High-fat diet affects ceramide content, disturbs mitochondrial redox balance, and induces apoptosis in the submandibular glands of mice," Biomolecules, vol. 9, no. 12, p. 877, 2019.

[37] U. Asmat, K. Abad, and K. Ismail, "Diabetes mellitus and oxidative stress-A concise review," Saudi Pharmaceutical Journal, vol. 24, no. 5, pp. 547-553, 2016.

[38] J. A. Ship, C. Decarli, R. P. Friedland, and B. J. Baum, "Diminished submandibular salivary flow in dementia of the alzheimer type," Journal of Gerontology, vol. 45, no. 2, pp. M61-M66, 1990.

[39] C. E. Sørensen, "Hyposalivation and poor dental health status are potential correlates of age-related cognitive decline in late midlife in Danish men," Frontiers in Aging Neuroscience, vol. 10, no. 10, 2018. 
[40] Y. Fathi, E. G. Hoseini, F. Atoof, and R. Mottaghi, "Xerostomia (dry mouth) in patients with COVID-19: a case series," Future Virology, vol. 16, no. 5, pp. 315-319, 2021.

[41] C. H. Shiboski, "Management of salivary hypofunction during and after radiotherapy," Oral Surgery, Oral Medicine, Oral Pathology, Oral Radiology and Endodontics, vol. 103, no. Suppl, pp. S66 e1-19, 2007.

[42] S. Folke, G. Paulsson, B. Fridlund, and B. Söderfeldt, "The subjective meaning of xerostomia-an aggravating misery," International Journal of Qualitative Studies on Health and Well-Being, vol. 4, no. 4, pp. 245-255, 2009.

[43] S. Fedele, A Wolff, F Strietzel, R. M López, S. R Porter, and Y. T Konttinen, "Neuroelectrostimulation in treatment of hyposalivation and xerostomia in Sjögren's syndrome: a salivary pacemaker," Journal of Rheumatology, vol. 35, no. 8, pp. 1489-1494, 2008.

[44] A. Wolff, P. C. Fox, S. Porter, and Y. T. Konttinen, "Established and novel approaches for the management of hyposalivation and xerostomia," Current Pharmaceutical Design, vol. 18, no. 34, pp. 5515-5521, 2012.

[45] H. Flink, Å. Tegelberg, J. E. Arnetz, and D. Birkhed, "Selfreported oral and general health related to xerostomia, hyposalivation, and quality of life among caries active younger adults," Acta Odontologica Scandinavica, vol. 78, no. 3, pp. 229-235, 2020.

[46] G. E. Gurvits and A. Tan, "Burning mouth syndrome," World Journal of Gastroenterology, vol. 19, no. 5, pp. 665-672, 2013.

[47] A. Nieuw Amerongen and E. Veerman, "Current therapies for xerostomia and salivary gland hypofunction associated with cancer therapies," Supportive Care in Cancer, vol. 11, no. 4, pp. 226-231, 2003.

[48] J. Guggenheimer and P. A. Moore, "Xerostomia," The Journal of the American Dental Association, vol. 134, no. 1, pp. 61-69, 2003.

[49] J. Epstein, "A double-blind crossover trial of Oral Balance gel and Biotene toothpaste versus placebo in patients with xerostomia following radiation therapy," Oral Oncology, vol. 35, no. 2, pp. 132-137, 1999.

[50] N. L. Rhodus and J. Bereuter, "Clinical evaluation of a commercially available oral moisturizer in relieving signs and symptoms of xerostomia in postirradiation head and neck cancer patients and patients with Sjögren's syndrome," Journal of Otolaryngology, vol. 29, no. 1, pp. 28-34, 2000.

[51] C. Spirk, S. Hartl, E. Pritz et al., "Comprehensive investigation of saliva replacement liquids for the treatment of xerostomia," International Journal of Pharmaceutics, vol. 571, p. 118759, 2019.

[52] M. M. Grisius, "Salivary gland dysfunction: a review of systemic therapies," Oral Surgery, Oral Medicine, Oral Pathology, Oral Radiology and Endodontics, vol. 92, no. 2, pp. 156-162, 2001.

[53] L. R. Wiseman and D. Faulds, "Oral pilocarpine," Drugs, vol. 49, no. 1, pp. 143-155, 1995.

[54] C. Scarantino, F. LeVeque, R. S. Swann et al., "Effect of pilocarpine during radiation therapy: results of RTOG 97-09, a phase III randomized study in head and neck cancer patients," Journal of Supportive Oncology, vol. 4, no. 5, pp. 252-258, 2006.

[55] Z. Nyárády, A. Németh, A. Bán et al., "A randomized study to assess the effectiveness of orally administered pilocarpine during and after radiotherapy of head and neck cancer," Anticancer Research, vol. 26, no. 2b, pp. 1557-1562, 2006.
[56] L. Berk, "Systemic pilocarpine for treatment of xerostomia," Expert Opinion on Drug Metabolism and Toxicology, vol. 4, no. 10, pp. 1333-1340, 2008.

[57] M. Gorsky, J. B. Epstein, J. Parry, M. S. Epstein, N. D. Le, and S. Silverman, "The efficacy of pilocarpine and bethanechol upon saliva production in cancer patients with hyposalivation following radiation therapy," Oral Surgery, Oral Medicine, Oral Pathology, Oral Radiology \& Endodontics, vol. 97, no. 2, pp. 190-195, 2004.

[58] J. R. Kouvaris, V. E. Kouloulias, and L. J. Vlahos, "Amifostine: the first selective-target and broad-spectrum radioprotector," The Oncologist, vol. 12, no. 6, pp. 738-747, 2007.

[59] F. G. Salum, "Salivary hypofunction: An update on therapeutic strategies," Gerodontology, vol. 35, 2018.

[60] B. J. Baum, I. Alevizos, C. Zheng et al., "Early responses to adenoviral-mediated transfer of the aquaporin-1 cDNA for radiation-induced salivary hypofunction," Proceedings of the National Academy of Sciences, vol. 109, no. 47, pp. 1940319407, 2012.

[61] A. Mobasheri and D. Marples, "Expression of the AQP-1 water channel in normal human tissues: a semiquantitative study using tissue microarray technology," American Journal of Physiology-Cell Physiology, vol. 286, no. 3, pp. C529C537, 2004.

[62] W. Wang, P. S. Hart, N. P. Piesco, X. Lu, M. C. Gorry, and T. C. Hart, "Aquaporin expression in developing human teeth and selected orofacial tissues," Calcified Tissue International, vol. 72, no. 3, pp. 222-227, 2003.

[63] B. J. Baum, C. Zheng, A. P. Cotrim et al., "Aquaporin-1 gene transfer to correct radiation-induced salivary hypofunction," Handbook of Experimental Pharmacology, Springer, Berlin, Germany, pp. 403-418, 2009.

[64] I. Alevizos, C. Zheng, A. P. Cotrim et al., "Late responses to adenoviral-mediated transfer of the aquaporin-1 gene for radiation-induced salivary hypofunction," Gene Therapy, vol. 24, no. 3, pp. 176-186, 2017.

[65] Safety of a single administration of AAV2hAQP1, an adenoassociated viral vector encoding human aquaporin-1 to one parotid salivary gland in people with irradiation-induced parotid salivary hypofunction, https://clinicaltrials.gov/ct2/ show/NCT02446249.

[66] A Phase 1 Open-Label, Dose Escalation Study to Determine the Optimal Dose, Safety, and Activity of AAV2hAQP1 in Subjects with Radiation-Induced Parotid Gland Hypofunction and Xerostomia.

[67] D. H. Jensen, R. S. Oliveri, S.-F. Trojahn Kølle et al., "Mesenchymal stem cell therapy for salivary gland dysfunction and xerostomia: a systematic review of preclinical studies," Oral Surgery, Oral Medicine, Oral Pathology and Oral Radiology, vol. 117, no. 3, pp. 335-342, 2014.

[68] V. K. Shanbhag, "Stem cells in management of xerostomia," International Journal of Dentistry and Oral Health, vol. 1, 2015.

[69] J.-Y. Lim, "Intraglandular transplantation of bone marrowderived clonal mesenchymal stem cells for amelioration of post-irradiation salivary gland damage," Oral Oncology, vol. 49, 2012.

[70] T. Kojima, S.-I. Kanemaru, S. Hirano et al., "Regeneration of radiation damaged salivary glands with adipose-derived stromal cells," The Laryngoscope, vol. 121, no. 9, pp. 1864-1869, 2011.

[71] C. Grønhøj, "Safety and efficacy of mesenchymal stem cells for radiation-induced xerostomia: a randomized, placebocontrolled phase 1/2 trial (MESRIX)," International Journal 
of Radiation Oncology, Biology, Physics, vol. 101, no. 3, pp. 581-592, 2018.

[72] D. Terlević Dabić, "The effectiveness of low-level laser therapy in patients with drug-induced hyposalivation: a pilot study," Photomed Laser Surg, vol. 34, no. 9, pp. 389-393, 2016.

[73] T. Barbieri, K. Costa, and L. Guerra, "Current alternatives in the prevention and treatment of xerostomia in cancer therapy," RGO - Revista Gaúcha de Odontologia, vol. 68, 2020.

[74] A. Teymoortash, F. Müller, J. Juricko et al., "Botulinum toxin prevents radiotherapy-induced salivary gland damage," Oral Oncology, vol. 45, no. 8, pp. 737-739, 2009.

[75] J. K. Mueller and W. J. Tyler, "A quantitative overview of biophysical forces impinging on neural function," Physical Biology, vol. 11, no. 5, p. 051001, 2014.

[76] A. Sehic, S. Guo, K.-S. Cho, R. M. Corraya, D. F. Chen, and T. P. Utheim, "Electrical stimulation as a means for improving vision," American Journal Of Pathology, vol. 186, no. 11, pp. 2783-2797, 2016.

[77] L. Zhuang, Z. Yang, X. Zeng et al., "The preventive and therapeutic effect of acupuncture for radiation-induced xerostomia in patients with head and neck cancer," Integrative Cancer Therapies, vol. 12, no. 3, pp. 197-205, 2013.

[78] S. Furness, "Interventions for the management of dry mouth: non-pharmacological interventions," Cochrane Database of Systematic Reviews, vol. 9, Article ID Cd009603, 2013.

[79] W. W. Weiss, H. S. Brenman, P. Katz, and J. A. Bennett, "Use of an electronic stimulator for the treatment of dry mouth," Journal of Oral and Maxillofacial Surgery, vol. 44, no. 11, pp. 845-850, 1986.

[80] E. Givens, "Update on xerostomia: current treatment modalities and future trends," General Dentistry, vol. 54, no. 2, pp. 99-101, 2006.

[81] G. V. Perminova IS and I. V. Rudenko, "Experience with using reflexotherapy in treating Sjogren's syndrome," Stomatologia, vol. 60, pp. 37-38, 1981.

[82] M. Steller, L. Chou, and T. E. Daniels, "Electrical stimulation of salivary flow in patients with sjögren's syndrome," Journal of Dental Research, vol. 67, no. 10, pp. 1334-1337, 1988.

[83] N. Talal, J. H. Quinn, and T. E. Daniels, "The clinical effects of electrostimulation on salivary function of Sjogren's syndrome patients. a placebo controlled study," Rheumatology International, vol. 12, no. 2, pp. 43-45, 1992.

[84] M. Blom, I. Dawidson, J.-O. Fernberg, G. Johnson, and B. Angmar-Månsson, "Acupuncture treatment of patients with radiation-induced xerostomia," European Journal of Cancer: Part B - Oral Oncology, vol. 32, no. 3, pp. 182-190, 1996.

[85] I. Dawidson, B. Angmar-Månsson, M. Blom, E. Theodorsson, and T. Lundeberg, "The influence of sensory stimulation (acupuncture) on the release of neuropeptides in the saliva of healthy subjects," Life Sciences, vol. 63, no. 8, pp. 659-674, 1998.

[86] M. Blom and T. Lundeberg, "Long-term follow-up of patients treated with acupuncture for xerostomia and the influence of additional treatment," Oral Diseases, vol. 6, no. 1, pp. 15-24, 2000.

[87] R. K. W. Wong, G. W. Jones, S. M. Sagar, A.-F. Babjak, and T. Whelan, "A Phase I-II study in the use of acupuncture-like transcutaneous nerve stimulation in the treatment of radiation-induced xerostomia in head-and-neck cancer patients treated with radical radiotherapy," International Journal of
Radiation Oncology, Biology, Physics, vol. 57, no. 2, pp. $472-480,2003$.

[88] I. A. Hargitai, R. G. Sherman, and J. M. Strother, "The effects of electrostimulation on parotid saliva flow: a pilot study," Oral Surgery, Oral Medicine, Oral Pathology, Oral Radiology and Endodontics, vol. 99, no. 3, pp. 316-320, 2005.

[89] F. Strietzel, R. Martín-Granizo, S. Fedele et al., "Electrostimulating device in the management of xerostomia," Oral Diseases, vol. 13, no. 2, pp. 206-213, 2007.

[90] J. H. Cho, W. K. Chung, W. Kang, S. M. Choi, C. K. Cho, and C. G. Son, "Manual acupuncture improved quality of life in cancer patients with radiation-induced xerostomia," Journal of Alternative and Complementary Medicine, vol. 14, no. 5, pp. 523-526, 2008.

[91] S. Ami and A. Wolff, "Implant-supported electrostimulating device to treat xerostomia: a preliminary study," Clinical Implant Dentistry and Related Research, vol. 12, no. 1, pp. 62-71, 2010.

[92] K. M. Pattani, C. M McDuffie, M Morgan, C Armstrong, and C. O Nathan, "Electrical stimulation of post-irradiated head and neck squamous cell carcinoma to improve xerostomia," Journal of the Louisiana State Medical Society, vol. 162, no. 1, pp. 21-25, 2010.

[93] R. K. W. Wong, J. L. James, S. Sagar et al., "Phase 2 results from radiation therapy oncology group study 0537," Cancer, vol. 118, no. 17, pp. 4244-4252, 2012.

[94] F. P. Strietzel, G. I. Lafaurie, G. R. B. Mendoza et al., "Efficacy and safety of an intraoral electrostimulation device for xerostomia relief: a multicenter, randomized trial," Arthritis and Rheumatism, vol. 63, no. 1, pp. 180-190, 2011.

[95] I. Alajbeg, D. P. Falcão, S. D. Tran et al., "Intraoral electrostimulator for xerostomia relief: a long-term, multicenter, open-label, uncontrolled, clinical trial," Oral Surgery, Oral Medicine, Oral Pathology and Oral Radiology, vol. 113, no. 6, pp. 773-781, 2012.

[96] R. Simcock, L. Fallowfield, K. Monson et al., "ARIX: a randomised trial of acupuncture $\mathrm{v}$ oral care sessions in patients with chronic xerostomia following treatment of head and neck cancer," Annals of Oncology, vol. 24, no. 3, pp. 776-783, 2013.

[97] S. Pattipati, R. Patil, G. Shirisharani, N. Kannan, B. Kumar, and R. Mohammed, "Effect of transcutaneous electrical nerve stimulation induced parotid stimulation on salivary flow," Contemporary Clinical Dentistry, vol. 4, no. 4, pp. 427-431, 2013.

[98] A. Vijayan, M. L. Asha, S. Babu, and S. Chakraborty, "Prospective phase II study of the efficacy of transcutaneous electrical nerve stimulation in post-radiation patients," Clinical Oncology, vol. 26, no. 12, pp. 743-747, 2014.

[99] Y. Zadik, I. Zeevi, N. Luboshitz-Shon et al., "Safety and efficacy of an intra-oral electrostimulator for the relief of dry mouth in patients with chronic graft versus host disease: case series," Medicina Oral, Patología Oral y Cirugía Bucal, vol. 19, no. 3, pp. e212-e219, 2014.

[100] H. Aggarwal, M. Pal-Singh, H. Mathur, S. Astekar, P. Gulati, and S. Lakhani, "Evaluation of the effect of transcutaneous electrical nerve stimulation (TENS) on whole salivary flow rate," Journal of clinical and experimental dentistry, vol. 7, no. 1, pp. e13-e17, 2015.

[101] A. Lakshman, G. Babu, and S. Rao, "Evaluation of effect of transcutaneous electrical nerve stimulation on salivary flow rate in radiation induced xerostomia patients: a pilot study," Journal of Cancer Research and Therapeutics, vol. 11, no. 1, pp. 229-233, 2015. 
[102] R. K. W. Wong, S. Deshmukh, G. Wyatt et al., "Acupuncturelike transcutaneous electrical nerve stimulation versus pilocarpine in treating radiation-induced xerostomia: results of RTOG 0537 phase 3 study," International Journal of Radiation Oncology, Biology, Physics, vol. 92, no. 2, pp. 220-227, 2015.

[103] Y. Hasegawa, K. Sugahara, S. Sano, A. Sakuramoto, H. Kishimoto, and Y. Oku, "Enhanced salivary secretion by interferential current stimulation in patients with dry mouth: a pilot study," Oral Surgery, Oral Medicine, Oral Pathology and Oral Radiology, vol. 121, no. 5, pp. 481-489, 2016.

[104] A. Konidena, D. Sharma, G. Puri, A. Dixit, D. Jatti, and R. Gupta, "Effect of TENS on stimulation of saliva in postmenopausal women with or without oral dryness-an interventional study," Journal of Oral Biology and Craniofacial Research, vol. 6, no. Suppl 1, pp. S44-s50, 2016.

[105] P. V. Aparna, S. L Sankari, M Deivanayagi, A Priyadharshini, C. K Vishnupriya, and B Niveditha, "Effect of transcutaneous electrical nerve stimulation on parotid saliva flow in patients with hyposalivation," Journal of Pharmacy and Bioallied Sciences, vol. 9, no. Suppl 1, pp. S142-s146, 2017.

[106] S. Dyasnoor, S. Kamath, and N. F. A. Khader, "Effectiveness of electrostimulation on whole salivary flow among patients with type 2 diabetes mellitus," The Permanente Journal, vol. 21, pp. 15-164, 2017.

[107] É.D. Paim, "Efeito agudo da transcutaneous electric nerve stimulation (TENS) sobre a hipossalivação induzida pela radioterapia na região de cabeça e pescoço: um estudo preliminar," CoDAS, vol. 30, 2018.

[108] A. Wolff, M Koray, G Campisi et al., "Electrostimulation of the lingual nerve by an intraoral device may lead to salivary gland regeneration: a case series study," Medicina Oral, Patologia Oral Y Cirugia Bucal, vol. 23, no. 5, pp. e552-e559, 2018.

[109] L. Y. Yang, H. M. Chen, Y. C. Su, and C. C. Chin, "The effect of transcutaneous electrical nerve stimulation on increasing salivary flow rate in hemodialysis patients," Oral Diseases, vol. 25, no. 1, pp. 133-141, 2019.

[110] E. Paim, "Effects of transcutaneous electrical nerve stimulation (TENS) on the salivary flow of patients with hyposalivation induced by radiotherapy in the head and neck region-a randomized clinical trial," Journal of Oral Rehabilitation, vol. 46, 2019.

[111] A. Ismail, "Impact of transcutaneous electrical nerve stimulation (TENS) on hyposalivation in type 2 diabetics," Bioscience Research, vol. 16, pp. 690-694, 2019.

[112] A. J. Iovoli, A. Ostrowski, C. I. Rivers et al., "Two- versus four-times weekly acupuncture-like transcutaneous electrical nerve stimulation for treatment of radiation-induced xerostomia: a pilot study," Journal of Alternative \& Complementary Medicine, vol. 26, no. 4, pp. 323-328, 2020.

[113] J. Koike, S. Nozue, Y. Ihara, and K. Takahashi, "Effects of Neuromuscular Electrical Stimulation (NMES) on salivary flow in healthy adults," Journal of Clinical and Experimental Dentistry, vol. 12, no. 8, pp. e777-e783, 2020.

[114] M. K. Garcia, Z. Meng, D. I. Rosenthal et al., "Effect of true and sham acupuncture on radiation-induced xerostomia among patients with head and neck cancer," JAMA network open, vol. 2, no. 12, Article ID e1916910, 2019. 